\title{
Effects of Eletro Deposition Process Parameters on the Tribological Properties of Ti (CN) Particles Reinforced Ni-base Alloy Composite Coatings
}

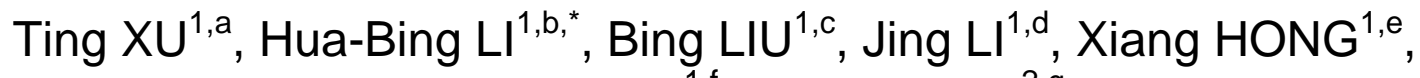 \\ Chu-Fan XIAO ${ }^{1, f}$, Yu-Min JIAO ${ }^{2, g}$ \\ ${ }^{1}$ College of Field Engineering, PLA University of Science and Technology, Nanjing 210007, China \\ ${ }^{2} 94679$ Troop, Nanjing 210038, China

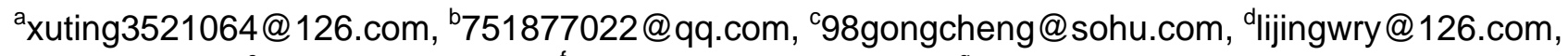

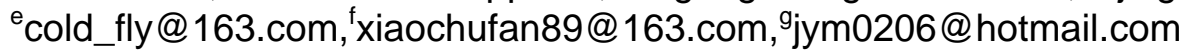 \\ ${ }^{*}$ Corresponding author
}

Keywords: Eletro Deposition, Aluminum Alloy, Ti (CN) Particle, Composite Coatings, Friction and Wear.

\begin{abstract}
The Ni-Co-Ti $(\mathrm{CN})$ composite coatings were prepared on aluminum alloy by eletro deposition technology. The effects of eletro deposition process parameters on the tribological properties of composite coatings were investigated, and the best eletro deposition process parameters were determined. The tribological behavior and mechanism of composite coatings were discussed. The results show that when the Ti $(\mathrm{CN})$ particle concentration is $20 \mathrm{~g} / \mathrm{L}$, current density is $4 \mathrm{~A} / \mathrm{dm}^{2}$ and the solution temperature is $40^{\circ} \mathrm{C}$, the microstructure of the composite coatings is compact with the biggest value of micro-hardness, and the composite coatings exhibit excellent wear resistance. The main wear mechanism is micro-cutting wear.
\end{abstract}

\section{Introduction}

As the important materials to realize the light equipment and improve motor performance, Aluminum alloy have been increasingly widely applied to equipment. But, the wear resistance of aluminum alloy is poor, which seriously affected the service life and reliability of aluminum alloy friction parts. In order to improve the situation, it becomes a hotspot to prepare the composite coatings that having good anti-friction and wear resistance performance on the aluminum alloy surface by composite technology ${ }^{[1-3]}$.

As a kind of widely used surface engineering technologies, eletro deposition technology has simple equipment and low cost and has been successfully applied to prepare wear resistant composite coating $^{[4-7]}$. Nowadays, there are many researches on wear resistant composite coatings of Ni-base alloy reinforced by hard ceramic particles, such as WC, SiC, TiC, TiN etc ${ }^{[8-12]}$. Ti (C, N) is a solid solution formed by $\mathrm{TiC}$ and $\mathrm{TiN}$, it has both the advantages of $\mathrm{TiC}$ and $\mathrm{TiN}$. Compared with TiC, Ti (C, N) show better toughness, wear resistance and chemical stability, while compared with $\mathrm{TiN}$, the hardness of $\mathrm{Ti}(\mathrm{C}, \mathrm{N})$ is higher and the friction coefficient of $\mathrm{Ti}(\mathrm{C}, \mathrm{N})$ is lower. So, Ti $(\mathrm{C}, \mathrm{N})$ is a kind of metal ceramic hard phase particles that having high hardness, good wear resistance, good oxidation resistance, good thermal conductivity and good chemical stability. So in this paper, the $\mathrm{Ti}(\mathrm{C}, \mathrm{N})$ particles reinforced Ni-base alloy composite coatings (Ni-Co-Ti $(\mathrm{C}, \mathrm{N})$ ) were prepared on the surface of aluminum alloy by eletro deposition technology and the effects of the $\mathrm{Ti}(\mathrm{CN})$ particle concentration, current density and the solution temperature on the tribological properties of composite coatings were investigated to provide experimental proofs and instructions for the composite coatings in engineering application. 


\section{Experimental}

\section{Specimen Preparation}

The 6061-T8 aluminum alloy was chosen as the substrate. The electrolysis nickel board(the purity $>99.9 \%$ ) was chosen as the soluble anode, which size is $50 \mathrm{~mm} \times 30 \mathrm{~mm} \times 10 \mathrm{~mm}$. Sulfate nickel plating liquid that added amount of $\mathrm{Ti}(\mathrm{C}, \mathrm{N})$ particles (the particle size range from $1 \mu \mathrm{m}$ to $5 \mu \mathrm{m}$ ) was chosen as the basis plating solution, which composition is shown in table 1 .

Tab.1 Plating Solution Composition of Ni-Co-Ti (C, N) Composite Coatings

\begin{tabular}{ccccccc}
\hline NiSO4 & $\mathrm{NiCl}$ & $\mathrm{CoSO} 4$ & $\begin{array}{c}\text { Boric } \\
\text { acid }\end{array}$ & Saccharin & $\begin{array}{c}\text { Ti(C,N) } \\
\text { particles }\end{array}$ & OP-10 \\
\hline $250 \mathrm{~g} / \mathrm{L}$ & $40 \mathrm{~g} / \mathrm{L}$ & $20 \mathrm{~g} / \mathrm{L}$ & $35 \mathrm{~g} / \mathrm{L}$ & $3 \mathrm{~g} / \mathrm{L}$ & $0 \sim 40 \mathrm{~g} / \mathrm{L}$ & $0.06 \mathrm{~mL} / \mathrm{L}$ \\
\hline
\end{tabular}

The prior treatment process of aluminum alloy is firstly degreasing and cleaning, and then electro deposition $\mathrm{Ni}-\mathrm{Co}-\mathrm{Ti}(\mathrm{CN})$ composite coatings. The eletro deposition process parameters were as follows: stirring speed of $500 \mathrm{r} / \mathrm{min}$, eletro deposition time of $180 \mathrm{~min}, \mathrm{Ti}(\mathrm{CN})$ particle concentration of $5 \mathrm{~g} / \mathrm{L}, 10 \mathrm{~g} / \mathrm{L}, 20 \mathrm{~g} / \mathrm{L}, 30 \mathrm{~g} / \mathrm{L}, 40 \mathrm{~g} / \mathrm{L}$ respectively, current density of $2 \mathrm{~A} / \mathrm{dm}^{2}, 4 \mathrm{~A} / \mathrm{dm}^{2}, 6 \mathrm{~A} / \mathrm{dm}^{2}$, $8 \mathrm{~A} / \mathrm{dm}^{2}$ respectively and solution temperature of $30^{\circ} \mathrm{C}, 40^{\circ} \mathrm{C}, 50^{\circ} \mathrm{C}, 60^{\circ} \mathrm{C}$ respectively.

\section{Tribological Tests and Surface Analysis}

The microstructure and worn surfaces of the Ni-Co-Ti $(\mathrm{C}, \mathrm{N})$ composite coatings were observed by scanning electronic microscopy (SEM) of QUANTA200. The hardness of the Ni-Co-Ti (C, N) composite coatings was measured by the DHV-1000 micro-hardness tester. The tribological tests were carried out in a ball-on-disc tribometer of HT-500 at room temperature. The upper specimen was a GCr15 steel ball with the diameter of $4.76 \mathrm{~mm}$. The down one was the Ni-Co-Ti $(\mathrm{C}, \mathrm{N})$ composite coatings. The GCr15 steel ball slid against the Ni-Co-Ti $(\mathrm{C}, \mathrm{N})$ coatings under dry sliding friction condition at the speed of $0.22 \mathrm{~m} / \mathrm{s}$, load of $8 \mathrm{~N}$ and time of $30 \mathrm{~min}$. The specimen wear losses were measured by the balance of TG328A with the accuracy of $0.1 \mathrm{mg}$.

\section{Results and Discussion}

\section{Effects of the Ti $(\mathrm{CN})$ Particle Concentration on the Tribological Properties of Ni-Co-Ti $(\mathrm{C}, \mathrm{N})$ Composite Coatings}

The wear loss and friction coefficients of the Ni-Co-Ti $(\mathrm{C}, \mathrm{N})$ composite coatings with the changes of $\mathrm{Ti}(\mathrm{CN})$ particle concentrations are shown in Fig.1. It is found that both first decreases then increases with the increase of the Ti $(\mathrm{CN})$ particle concentrations. When the Ti $(\mathrm{CN})$ particle concentrations is $20 \mathrm{~g} / \mathrm{L}$, the wear loss is the least $(2.6 \mathrm{mg})$, only for $1 / 2$ of the Ni-Co coatings (Fig.1a), the friction coefficients is also the least (0.57), reduced by $20 \%$ than that of the Ni-Co coatings (Fig.1b).

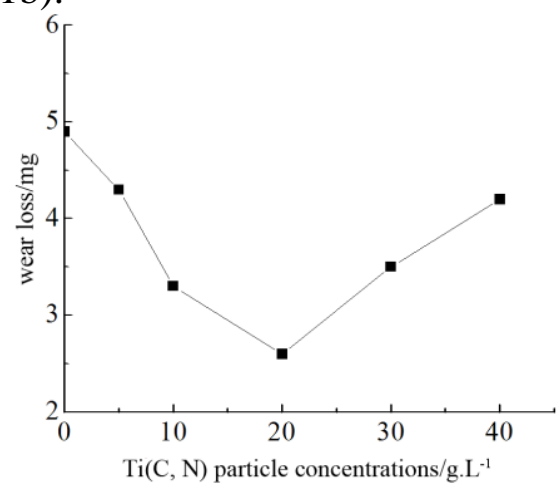

(a) Wear Loss

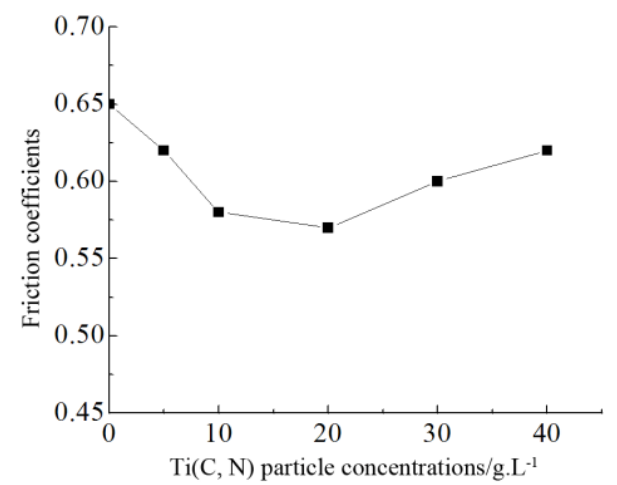

(b) Friction Coefficients

Fig.1 Friction and Wear Results VS Ti (CN) Particle Concentrations 


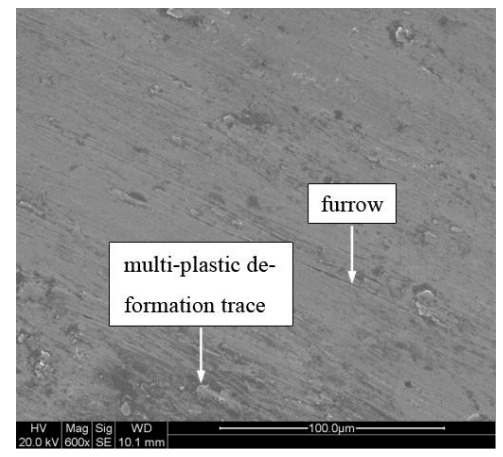

(a) $10 \mathrm{~g} / \mathrm{L}$

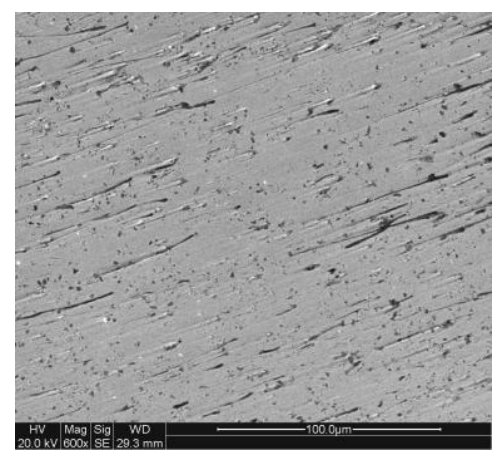

(b) $20 \mathrm{~g} / \mathrm{L}$

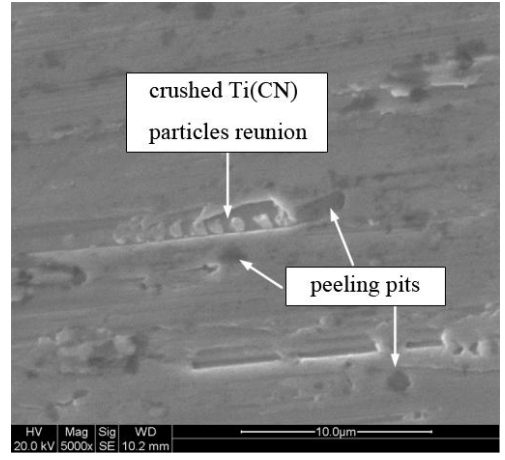

(c) $40 \mathrm{~g} / \mathrm{L}$

Fig.2 SEM Images of the Worn Surfaces of Composite Coatings under Different Ti (CN) Particle Concentrations Conditions

The SEM images of the worn surfaces of composite coatings under different $\mathrm{Ti}(\mathrm{CN})$ particle concentrations conditions are shown in Fig.2. As shown in Fig.2(a), When the Ti (CN) particle concentrations is $10 \mathrm{~g} / \mathrm{L}$, there are many severe plastic deformation areas and furrows trace on the worn surface, this is because at this time, the $\mathrm{Ti}(\mathrm{CN})$ particle concentrations is less, the micro-hardness of the $\mathrm{Ni}-\mathrm{Co}-\mathrm{Ti}(\mathrm{C}, \mathrm{N})$ composite coatings is relatively lower $(550 \mathrm{HV})$, so the main wear mechanisms are micro-cutting wear and multi-plastic deformation wear. As shown in Fig.2(b), when the Ti $(\mathrm{CN})$ particle concentrations is $20 \mathrm{~g} / \mathrm{L}$, the worn surface is relatively flat accompanied with many discontinuous furrows, so the main wear mechanism is slight micro-cutting wear, this is because the micro-hardness of $20 \mathrm{~g} / \mathrm{L}$ composite coatings is the highest $(574 \mathrm{HV})$, in addition, the dispersing of $\mathrm{Ti}(\mathrm{C}, \mathrm{N})$ particles may effectively prevent wear and tear and the plough cut phenomenon and greatly improve the wear resistance of the composite coatings. But when the Ti (CN) particle concentrations is too high $(40 \mathrm{~g} / \mathrm{L})$, it can be seen from the Fig.2(c) that there are serious furrows and multi-plastic deformation trace as well as micro peeling pits on the worn surface, this is because the $\mathrm{Ti}(\mathrm{CN})$ particles reunite together but combined loosely, they would broken and fall off under the repeated extrusion in the friction process, which result in the three body abrasive wear and then reduce the wear resistance of composite coatings.

\section{Effects of Current Density on the Tribological Properties of Ni-Co-Ti (C, N) Composite Coatings}

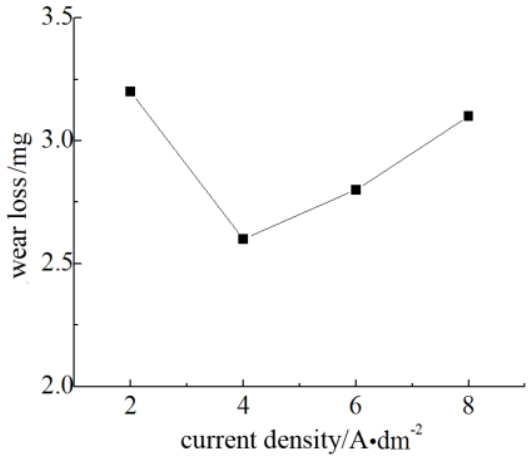

(a) Wear Loss

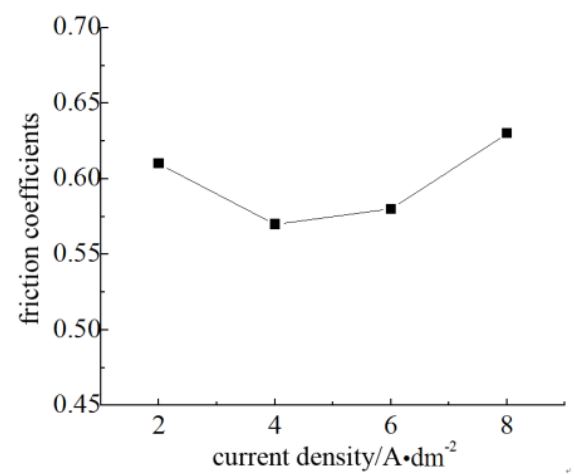

(b) Friction Coefficients

Fig.3 Friction and Wear Results VS Current Density

The wear loss and friction coefficients of the Ni-Co-Ti $(\mathrm{C}, \mathrm{N})$ composite coatings with the changes of current density are shown in Fig.3. It is found that both first decreases then increases with the increase of current density. When the current density is $4 \mathrm{~A} / \mathrm{dm}^{2}$, the wear loss is the least of 
2.6mg (Fig.3(a)) and the friction coefficients is also the least of 0.57 (Fig.3(b)).

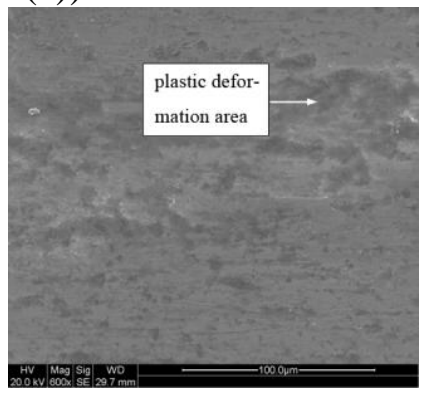

(a) $2 \mathrm{~A} / \mathrm{dm} 2$

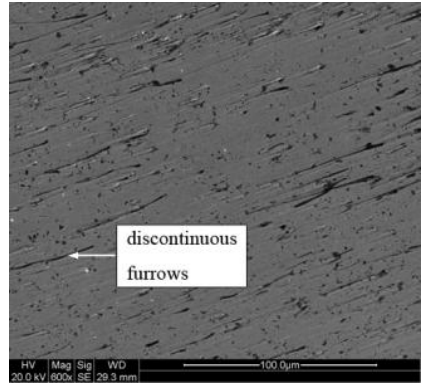

(b) $4 \mathrm{~A} / \mathrm{dm} 2$

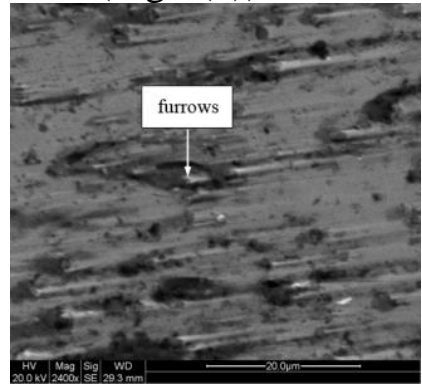

(c) $8 \mathrm{~A} / \mathrm{dm} 2$

Fig.4 SEM Images of the Worn Surfaces of Composite Coatings under Different Current Density Conditions

Fig.4 shows the SEM images of the worn surfaces of composite coatings under different current density conditions. When the current density is $2 \mathrm{~A} / \mathrm{dm}^{2}$, there are obvious plastic deformation area accompanied with microscopic pits and furrows on the worn surface (Fig.4a), so the main wear mechanisms are multi-plastic deformation wear and micro-crack wear. This is because the micro-hardness of $2 \mathrm{~A} / \mathrm{dm}^{2}$ coating is relatively lower $(553.3 \mathrm{HV})$, the coating surface was plough cut by the frictional couple and occurred plastic deformation, at the same time, the micro cracks firstly initiated in the stress concentration area of plastic deformation zone and gradually expand to the surface, in turn, the material break and peel off to pits. When the current density increases to $4 \mathrm{~A} / \mathrm{dm}^{2}$, the worn surface is relatively flat just accompanied with some discontinuous furrows (Fig.4b), so the main wear mechanism is slight micro-cutting wear, this is because the micro-hardness of $4 \mathrm{~A} / \mathrm{dm}^{2}$ coating is the highest $(574 \mathrm{HV})$, the $\mathrm{Ti}(\mathrm{CN})$ particles embedded firmly and the pinning effect is obvious, which effectively inhibit the expansion of the micro cracks and dislocation motion, and reduce the plastic deformation of $\mathrm{Ni}$-Co substrate metal, the dispersion strengthening effect is obvious, thus the wear resistance of composite coating was improved. As the current density increases to $8 \mathrm{~A} / \mathrm{dm}^{2}$ (Fig.4c), it is found that there are more furrows and micro cutting wear traces on the worn surface. It is because the micro-hardness of $8 \mathrm{~A} / \mathrm{dm}^{2}$ coating become lower $(566.7 \mathrm{HV})$, in addition, the cathode current density is bigger and the hydrogen evolution of the cathode surface is serious, which make a part of the $\mathrm{Ti}(\mathrm{CN})$ particles and matrix metal combined weakly, so some Ti $(\mathrm{CN})$ particles fall off and lead to abrasive wear.

\section{Effects of Solution Temperature on the Tribological Properties of Ni-Co-Ti $(\mathrm{C}, \mathrm{N})$ Composite Coatings}

The wear loss and friction coefficients of the Ni-Co-Ti $(\mathrm{C}, \mathrm{N})$ composite coatings vs solution temperature are shown in Fig.5. It can be seen from the Fig.5(a) that when the solution temperature is $40^{\circ} \mathrm{C}$, the wear loss is the least $(2.6 \mathrm{mg})$. As the solution temperature increases from $30^{\circ} \mathrm{C}$ to $60^{\circ} \mathrm{C}$, the friction coefficients has a little change within the scope of 0.56 to 0.59 (Fig.5(b)).

Under different solution temperature conditions, the SEM images of the worn surfaces of composite coatings are respectively shown in Fig.6. As shown in Fig.6a, when the solution temperature is $30^{\circ} \mathrm{C}$, there are many plough traces and pits on the worn surface, so the main wear mechanism are micro-cutting wear and microscopic peeling wear. When the solution temperature is $40^{\circ} \mathrm{C}$, the worn surface is relatively flat only accompanied with a small amount of thin shallow scratches (Fig.6b), so the main wear mechanism is slight micro-cutting wear. When the solution temperature is $60^{\circ} \mathrm{C}$, the solution stability reduces, the comprehensive performance of composite coating becomes poorer and the micro-hardness of the composite coating is relatively lower 
(556.1HV), which result in the wear resistance of composite coatings reducing. It can be seen from the Fig.6c that there are multi-plastic areas and local peeling off traces, so the main wear mechanisms are multi-plastic wear and micro-cutting wear.

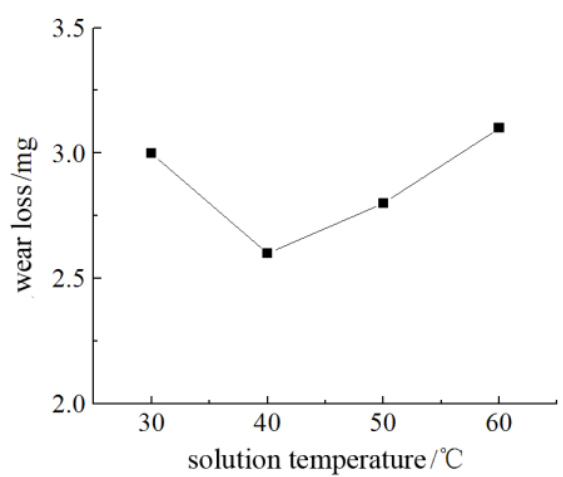

(a) Wear Loss

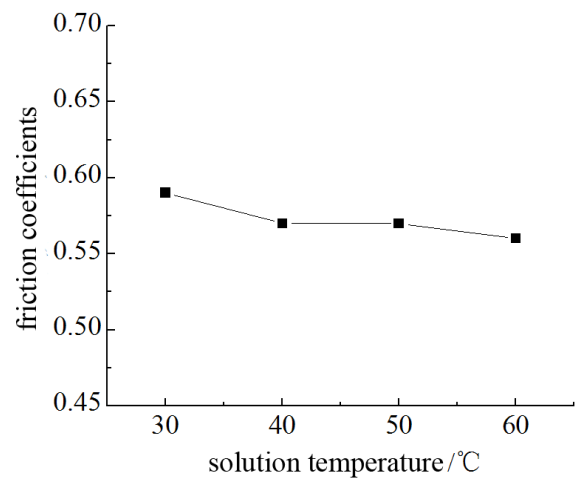

(b) Friction Coefficients

Fig.5 Friction and Wear Results VS Solution Temperature

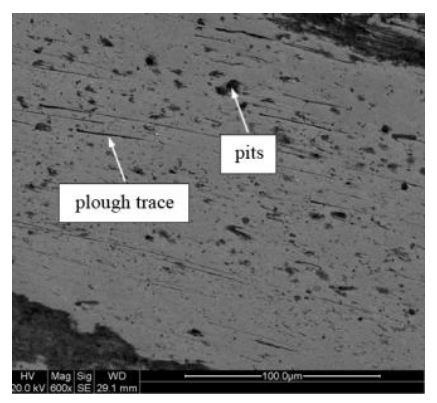

(a) $30^{\circ} \mathrm{C}$

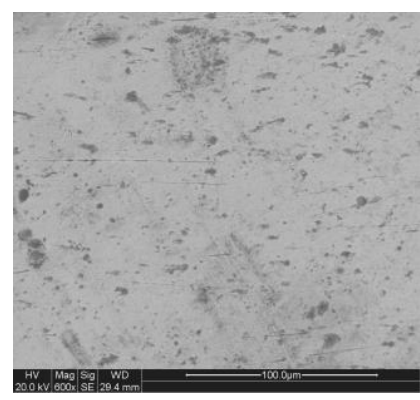

(b) $40^{\circ} \mathrm{C}$

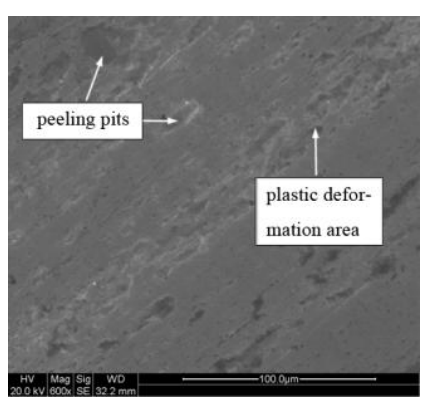

(c) $60^{\circ} \mathrm{C}$

Fig.6 SEM Images of the Worn Surfaces of Composite Coatings under Different Solution Temperature Conditions

\section{Conclusions}

1) When the $\mathrm{Ti}(\mathrm{CN})$ particle concentration is $20 \mathrm{~g} / \mathrm{L}$, the wear loss is the least $(2.6 \mathrm{mg})$, the friction coefficients is also the least (0.57), the main wear mechanism is slight micro-cutting wear.

2) When the current density is $4 \mathrm{~A} / \mathrm{dm}^{2}$, the wear loss is the least $(2.6 \mathrm{mg})$, the friction coefficients are also the least (0.57), and the main wear mechanism is slight micro-cutting wear. If the current density is too big or too small, the wear resistance of composite coating will reduce, the wear mechanisms are micro-cutting wear, multi-plastic wear and micro fracture wear.

3) When the solution temperature is $40^{\circ} \mathrm{C}$, the wear loss is the least $(2.6 \mathrm{mg})$, the main wear mechanism is micro-cutting wear. With the solution temperature increases or decreases, the wear mechanisms change to micro fracture wear, multi-plastic wear and micro-cutting wear.

\section{References}

[1] Dejian Nie, Wensi Chen, Mingqiang Luo. The research status of aluminum alloy surface modification technology [C]. The Vol of $5^{\text {th }}$ aluminum technology international conference. Guangzhou, 2013.

[2] Nasha Huang, Yihua Ni, Jiangxin Yang etc. The research status and progress of aluminum alloy surface modification technology [J]. Light industry machinery, 2010, 28 (4): 4-7.

[3] Xin Chu, Xin Ren, Shengzhi Hao etc. The development status of aluminum alloy surface modification technology [J]. The hot working processes, 2010.39 (20): 123-127. 
[4] Hetong Guo, Sanyuan Zhang. Composite electroplating technique [M]. Beijing, Chemical industry press, 2006.

[5] Haifei Zhou, Liwei Zhu, Zhouhai Qian. The research work of codeposition process of composite electrodeposition[J]. Electroplating and coating, 2013.32 (3): 50-53.

[6] Huan Zhang, Zhongcheng Guo, Yuehai Song. New trend in the research of composite electrodeposition [J]. Electroplating and coating, 2003, 22 (2): 29-34.

[7] Aruna S T, William Grips V K, Rajam K S. Ni-based electrodeposited composite coating exhibiting improved microhardness, corrosion and wear resistance properties [J]. Journal of Alloys and Compounds, 2009, 468 (1/2): 546-552.

[8] Robin A, De Santana J C P, Sartoai A F. Co-electro deposition and characterization of Cu-Si3N4 composite coatings [J]. Surface and Coatings Technology, 2011, 205 (19): 4596-4601.

[9] Benea L, Bonora P L, Borello A, et al. Preparation and investigation of nanostructured SiC-nickel layers by electro deposition [J]. Solid State Ionics, 2002, 151 (1/4): 89-95.

[10] Medeliene V. The influence of $\mathrm{B} 4 \mathrm{C}$ and $\mathrm{SiC}$ additions on the morphological, physical, chemical and corrosion properties of Ni coatings [J]. Surface and Coatings Technology, 2002, 154 (1): 104-111.

[11] He X Z, Wang Y X, Sun X, et al. Preparation and investigation of Ni-Diamond composite coatings by electrodeposition [J]. Nanoscience and Nanotechnology Letters, 2012, 4 (1): 48-52.

[12] Li Q, Song G M, Zhang Y Z. Microstructure and dry sliding wear behavior of laser clad Ni-based alloy coating with the addition of SiC [J]. Wear, 2003, 254:222-229. 